\title{
OPTIMALISASI FORMULASI BROWN RICE NOODLE DENGAN APLIKASI PROGRAM LINIER
}

\author{
Sholichin ${ }^{1}$, Muhammad Supli Effendi ${ }^{2}$, Yusep Ikrawan ${ }^{3}$ \\ ${ }^{1}$ Program Studi D III Gizi Cirebon, JI. KS Tubun No. 58 Cirebon, Jawa Barat. \\ ${ }^{2,3}$ Program Magister Teknologi pangan Universitas pasundan, JI. Sumatera No. 34 Bandung. \\ Email: akhi ikin@yahoo.com \\ Tanggal submisi: 05 November 2018 ; Tanggal penerimaan: 02 Januari 2019 (diisi oleh \\ pengelola jurnal)
}

\begin{abstract}
ABSTRAK
Mi merupakan produk yang popular karena disukai dan cara penyajiannya mudah dan cepat, namun bahan baku berupa gandum masih harus impor, sehingga perlu upaya substitusi bahan tersebut.Tujuan penelitian ini adalah mengoptimalkan formulasi Brown Rice Noodle dengan aplikasi program linier. Penelitian ini merupakan penelitian eksperimen di laboratorium menggunakan Rancangan Acak Lengkap (RAL) terdiri 5 faktor formulasi yaitu F1 (tepung brown rice $44,9 \%$ dan tapioka 0\%), F2 (tepung brown rice 42,1\% dan tapioka 2,8\%), F3 (tepung brown rice $39,3 \%$ dan tapioka 5,6\%), F4 (tepung brown rice $36,5 \%$ dan tapioka 8,4\%), dan F5 (tepung brown rice $33,7 \%$ dan tapioka $11,2 \%$ ). Hasil penelitian berdasarkan uji fisik brown rice noodle diketahui bahwa F5 memiliki karakteristik adonan yang paling mudah dibentuk menjadi mi, dan memiliki karakteristik mi kering yang paling baik dari segi bentuk maupun tekstur. Selain itu, F5 memiliki daya serap air tertinggi (138,5\%) dan cooking loss(17,3\%). Hasil uji organoleptik brown rice noodle secara keseluruhan, produk terbaik adalah F5 (nilai rerata 3,975). Adapun hasil uji kimia brown rice noodle diperoleh bahwa semua formula telah memenuhi standar mutu I mi kering dengan kadar protein minimal 11\% dan kadar air maksimal 8\%, kecuali F2 memiliki kadar air sedikit lebih tinggi $(8,26 \%)$.
\end{abstract}

Kata kunci: formulasi, noodle, program linier

\begin{abstract}
Noodle is a popular product for the preferred and easy and quick way of presentation, but raw materials such as wheat still to be imported, so that the necessary efforts to substitute these substances. The aim of the research is the use of linear programming application in determining the formulation of Brown Rice Noodle. The research was laboratory experiment uses completely randomized design (CRD) which consist of 5 formulation factors: F1 (brown rice flour $44,9 \%$ and tapioca $0 \%$ ), F2 (brown rice flour 42,1\% and tapioca 2,8\%), F3 (brown rice flour $39,3 \%$ and tapioca 5,6\%), F4 (brown rice flour $36,5 \%$ and tapioca $8,4 \%$ ), and F5 (brown rice flour $33,7 \%$ and tapioca $11,2 \%)$. Based on linear programming applications, the physical test of brown rice noodle known that F5 has the characteristics of the most malleable dough to be made into noodles, and has characteristics of dried noodle which is the best in terms of both form and texture. In addition, F5 has the highest water absorption (138,5\%) and the lowest cooking loss $(17,3 \%)$. Based on overall the organoleptic test of brown rice noodle, the best product is F5 (average value 3,975). However based on the chemical test of brown rice noodle has been obtained that all formulas have fulfilled the quality standard one dried noodle with the minimum protein content of $11 \%$ and maximum water content is $8 \%$, except $\mathrm{F} 2$ has a slightly higher water content $(8,26 \%)$.
\end{abstract}


Key word: formulation, noodle, linear programming;

\section{PENDAHULUAN}

Mi termasuk produk popular karena disukai dan cara penyajiannya mudah dan cepat (Sugiyono, dkk, 2011). Konsumsi mi instan masyarakat Indonesia menempati posisi kedua di dunia dengan rerata konsumsi sebanyak 75 bungkus per kepala per tahun (Arfani, 2012; Kabar24, 2012).

Tingginya tingkat konsumsi mi instan di Indonesia terjadi karena pergeseran konsumsi makanan masyarakat dari beras ke mi instan. Pertumbuhan konsumsi mi instan rerata per tahun sekitar 10\%-15\%. Pertumbuhan konsumsi mi instan lebih tinggi dibandingkan beras karena masyarakat menganggap mi instan lebih praktis, harganya terjangkau, rasanya yang dapat diterima oleh masyarakat serta terjamin ketersediaannya (Tabloid Pasar, 2012).

Mi biasanya terbuat dari terigu yang bahan bakunya gandum masih harus impor. Konsumsi tepung terigu Indonesia terus meningkat. Volume impor gandum Indonesia pada 2011 mencapai 5,4 juta metric ton. Pada 2012, volume impor gandum
Indonesia naik menjadi 6,2 juta metric ton. Hingga semester I tahun 2013, konsumsi mencapai 2,6 juta metric ton atau naik 1,08 persen dibandingkan periode yang sama tahun 2012 (Beranda, 2013; Merdeka, 2013; Sindonews, 2013; Tempo, 2013). Tingginya impor gandum disebabkan masyarakat Indonesia gemar mengkonsumsi mi instan dan roti (Merdeka, 2013). Konsumsi gandum Indonesia per tahun mencapai 21 kg per kapita. Konsumsi ini merupakan terbesar kedua setelah beras. Seluruh kebutuhan gandum di Indonesia saat ini masih 100 persen impor (Sindonews, 2013).

Bahan baku utama mi dari terigu dapat disbustitusi dengan tepung beras (Hizni \& Sholichin, 2014; Marti et al., 2010; Charutigon et al., 2008). Beras merupakan salah satu komoditas dengan nilai gizi yang baik dan di beberapa daerah di Indonesia digunakan sebagai makanan pokok. Berdasarkan data Susenas tahun 2005 2009, perkembangan konsumsi beras berturut-turut sejak 2005 - 2009 yaitu $288,30 \mathrm{gr} / \mathrm{kap} / \mathrm{hr} ; 285,04 \mathrm{gr} / \mathrm{kap} / \mathrm{hr} ; 274,03$ 
$\mathrm{gr} / \mathrm{kap} / \mathrm{hr} ; 287,26 \mathrm{gr} / \mathrm{kap} / \mathrm{hr}$. Dalam penelitian ini, dilakukan diversifikasi pangan horizontal berupa penggantian bahan baku utama mi dari terigu dengan beras, dan diversifikasi pangan vertikal yaitu beras yang biasa dikonsumsi dalam bentuk nasi menjadi olahan mi (Khomsan, dkk, 2010).

Tepung beras berbeda dengan tepung terigu yang mudah dibentuk menjadi olahan mi karena kandungan glutennya. Sehingga, substitusi terigu dengan tepung beras, dilakukan modifikasi dalam hal pengolahan dengan memanfaatkan prinsip gelatinisasi pati dari beras. Menurut Cuevas et al (2010), gelatinisasi adalah proses pecahnya granula pati yang bersifat tidak dapat kembali (irreversible). Suhu gelatinisasi berbeda-beda bagi tiap jenis pati dan merupakan suatu kisaran. Menurut Cuevas et al (2010), suhu gelatinisasi beras berkisar $70-75^{\circ} \mathrm{C}$. Sedangkan menurut Winarno (2008) suhu gelatinisasi beras berkisar $68-78^{\circ} \mathrm{C}$.

Tepung Beras yang digunakan dalam penelitian ini menggunakan konsep green product. Menurut Hasnelly (2011), konsep green product yaitu produk memiliki dampak rendah terhadap lingkungan, yaitu dapat mencegah dan meminimalisasi limbah. Oleh karena itu, agar dapat menggunakan konsep green product, maka beras yang digunakan adalah brown rice atau beras pecah kulit yang masih memiliki kandungan gizi lebih tinggi dibandingkan beras giling sempurna, terutama dalam protein $(7,4 \mathrm{gr} / 100 \mathrm{gr}$ bahan), kalsium (12 $\mathrm{mg} / 100 \mathrm{gr}$ bahan) dan phopor (290 mg/100 gr bahan). Dalam proses pengolahannya, beras akan dijadikan tepung beras. Namun, kandungan protein tepung beras $(7 \mathrm{gr} / 100$ gr bahan) masih lebih rendah dibandingkan protein dalam terigu (8,9 gr/100 gr bahan). Oleh karena itu, untuk meningkatkan kekurangan protein dalam pembuatan Brown Rice Noodle, dapat ditingkatkan dengan penambahan tepung kacang kedelai yang merupakan sumber protein yang baik. Adapun kacang kedelai yang digunakan dalam bentuk tepung dengan kandungan protein sebesar $35,9 \mathrm{gr} / 100 \mathrm{gr}$ bahan (Nio, 2012; Persagi, 2009). 
Tujuan penelitian ini adalah mengoptimalkan formulasi Brown Rice Noodle dengan aplikasi program linier. Selanjutnya, dilakukan uji fisik, organoleptik dan kimia

\section{METODE PENELITIAN}

\section{Bahan}

Bahan baku utama formulasi brown rice noodle yaitu tepung brown rice (beras pecah kulit) varietas IR 64, tapioka dan kacang kedelai putih. Tepung brown rice diperoleh dari penggilingan padi di Kabupaten Cirebon, sedangkan bahan bakuutama lainnya diperoleh dari pasar tradisional di Kabupaten Cirebon. Bahan kimia yang digunakan untuk analisis kimia (kadar protein dan air).

Alat

Peralatan utama yang digunakan meliputi alat-alat pembuatan Brown Rice Noolde, uji fisik, uji organoleptik, dan analisis kimia (kadarprotein dan air).

\section{Tahapan Penelitian}

Tahap pertama penelitian adalah analisis kimia semua bahan baku (kadar protein dan air) sebagai persyaratan penggunaan aplikasi program linier. Tahap berikutnya adalah pemanfaatan aplikasi program linier untuk mendapatkan formulasi yang optimum. Selanjutnya dilakukan pembuatan brown rice noodle. Tahap berikutnya adalah menganalisis semua formulasi dengan uji fisik, organoleptik dan kimia (kadar protein dan air).

Formulasi brown rice noodle. Aplikasi program linier dapat dilakukan jika sudah tersedia data analisis kimi (kadar protein dan air) semua bahan baku termasuk harga tiap bahan baku. Formulasi bertujuan untuk mendapatkan formula optimum yaitu memenuhi syarat mutu I mi kering berdasrkan SNI 01-2974-1996, yaitu kadar protein minimal $11 \%$ dan kadar air maksimal $8 \%$ dengan biaya yang rendah (formulasi dapat dilihat pada Tabel 2). Optimalisasi formulasi Brown Rice Noodle dengan program linier dilakukan melalui tahapan sebagai berikut:

1. Penetapan variabel

a. Variabel keputusan (variabel berubah): tepung brown rice, 
tapioka, tepung kacang kedelai, air, agar-agar, carboxymethyl cellulose (CMC), garam, baking powder dan tartazine yellow.

b. Variabel peubah keputusan (variabel tetap): protein dan air.

Adapun model variabel formula Brown Rice Noodle mengacu pada Siringoringo (2005) dan Herjanto (2008) sebagai berikut:

Tabel 1. Model variabel formulasi brown rice noodle

\begin{tabular}{|c|c|c|c|}
\hline $\begin{array}{c}\text { Bahan Baku } \\
(\mathrm{Xn})\end{array}$ & $\begin{array}{l}\text { Protein } \\
\left(\mathrm{A}_{1}\right)\end{array}$ & $\begin{array}{l}\text { Air } \\
\left(A_{2}\right)\end{array}$ & $\begin{array}{l}\text { Naragalempergacu } \\
\text { (Cn) }\end{array}$ \\
\hline Tepung Brown Rice $\left(\mathrm{X}_{1}\right)$ & $A_{11}$ & $A_{21}$ & Sholichin (2014 \\
\hline Tapioka $\left(X_{2}\right)$ & $A_{12}$ & $A_{22}$ & $\mathrm{C}_{2}$ \\
\hline Tepung Kacang Kedelai $\left(\mathrm{X}_{3}\right)$ & $A_{13}$ & $A_{23}$ & $\mathrm{C}_{3}$ \\
\hline $\operatorname{Air}\left(\mathrm{X}_{4}\right)$ & $\mathrm{A}_{14}$ & $A_{24}$ & dalamepembuata \\
\hline Agar-agar $\left(X_{5}\right)$ & $A_{15}$ & $A_{25}$ & $\mathrm{C}_{5}$ \\
\hline Carboxymethyl Cellulose $\left(\mathrm{X}_{6}\right)$ & $A_{16}$ & $A_{26}$ & $\mathrm{C}_{6}$ \\
\hline $\operatorname{Garam}\left(\mathrm{X}_{7}\right)$ & $A_{17}$ & $A_{27}$ & $\mathrm{C}_{7}$ \\
\hline Baking powder $\left(\mathrm{X}_{8}\right)$ & $A_{18}$ & $A_{28}$ & $\mathrm{C}_{8}$ \\
\hline Tartazine Yellow $\left(\mathrm{X}_{9}\right)$ & $A_{19}$ & $A_{29}$ & $\mathrm{C}_{9}$ \\
\hline $\begin{array}{l}\text { Syarat SNI 01-2974-1996 } \\
\text { (Mutu I) }\end{array}$ & $\begin{array}{l}\text { Min } \\
11 \%\end{array}$ & $\begin{array}{l}\text { Maks } \\
8 \%\end{array}$ & \\
\hline
\end{tabular}

Tabel 2.Komposisi bahan (\%) berdasarkan jenis formula

\begin{tabular}{lccccc}
\hline \multirow{2}{*}{ Bahan Baku } & \multicolumn{5}{c}{ Jenis Formula } \\
\cline { 2 - 6 } & $\mathrm{F} 1$ & $\mathrm{~F} 2$ & $\mathrm{~F} 3$ & $\mathrm{~F} 4$ & $\mathrm{F5}$ \\
\hline Tepung Brown Rice & 44,9 & 42,1 & 39,3 & 36,5 & 33,7 \\
Tapioka & 0,0 & 2,8 & 5,6 & 8,4 & 11,2 \\
Tepung Kedelai & 11,2 & 11,2 & 11,2 & 11,2 & 11,2 \\
Air & 39,3 & 39,3 & 39,3 & 39,3 & 39,3 \\
Agar-agar & 2,8 & 2,8 & 2,8 & 2,8 & 2,8 \\
Carboxy Methyl Celulose & 0,6 & 0,6 & 0,6 & 0,6 & 0,6 \\
Baking Powder & 0,6 & 0,6 & 0,6 & 0,6 & 0,6 \\
Garam & 0,6 & 0,6 & 0,6 & 0,6 & 0,6 \\
Tartrazine yellow & 0,2 & 0,2 & 0,2 & 0,2 & 0,2 \\
\hline Total & 100 & 100 & 100 & 100 & 100 \\
\hline
\end{tabular}

\section{Prosedur Pembuatan Brown Rice}

Noodle. Pembuatan Brown Rice penelitian Hizni dan dan Merdiyanti (2008) mi kering. 


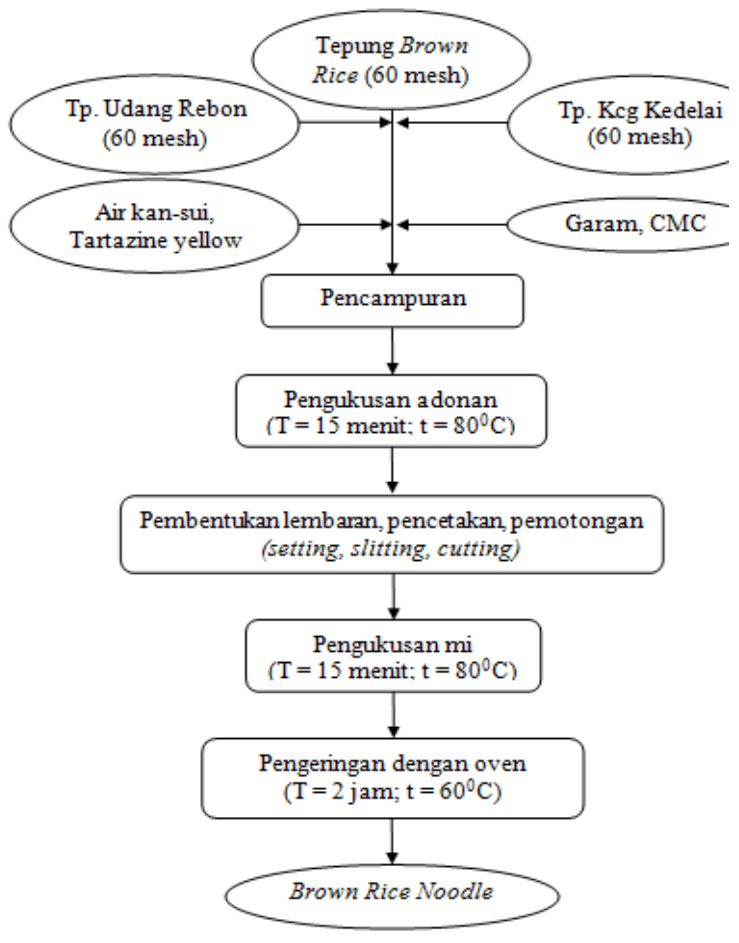

Gambar 1.Diagram Alir Pembuatan Brown Rice Noodle

Uji fisik. Pengujian fisik meliputi karakteristik adonan, karakteristik mi kering, daya serap air dan cooking loss. Daya serap air menggunakan rumus sebagai berikut:

$$
\text { Daya serap air }(\%)=\frac{B-A}{A} \times 100 \%
$$

keterangan:

A : berat sampel sebelum direhidrasi

$B$ : berat sampel setelah direhidrasi

Sedangkan data cooking loss diperoleh menggunakan rumus sebagai berikut:

$$
\text { cooking loss }(\%)=\frac{A-B}{A} \times 100 \%
$$

keterangan:

$A$ : berat kering sampel sebelum direbus
B : berat kering sampel setelah direbus

Uji organoleptik. Pengujian organoleptik diperoleh berdasarkan hasil uji hedonik (tingkat kesukaan) oleh panelis non standar sebanyak 30 orang (SNI 01-23462006) yang meliputi atribut warna, aroma, rasa dan tekstur dengan 7 skala penilaian yaitu Sangat Tidak Suka (Skala 1), Tidak Suka (Skala 2), agak tidak suka (Skala 3), Agak Suka (Skala 4), Suka (Skala 5), Sangat Suka (Skala 6), Sangat Suka Sekali (Skala 7).Penentuan produk terbaik berdasarkan rata-rata penilaian keseluruhan terhadap seluruh atribut.

Uji kimia.Data uji kimia diperoleh berdasarkan analisis terhadap kadar protein dankadar air.

\section{Analisis Data}

Data uji fisik, organoleptik dan kimia dianalisis secara deskriptif. Untuk mengetahui perbedaan tiap formula dilakukan analisis menggunakan Anova (analysis of variance). Jika ada perbedaan yang nyata diantara formula, maka digunakan uji lanjut Duncan yang dapat 
menyatakan perbedaan diantara masingmasing perlakuan tersebut.

\section{HASIL DAN PEMBAHASAN}

Formula optimasi dengan aplikasi

program linier dapat dilihat pada tabel 3 .

Tabel 3. Formulasi Brown Rice Noodle dengan Aplikasi Program Linier

\begin{tabular}{|c|c|c|c|c|c|c|c|c|c|c|c|c|c|c|c|c|c|c|c|c|}
\hline \multirow{3}{*}{$\begin{array}{l}\text { Bahan } \\
\text { Baku }\end{array}$} & \multicolumn{4}{|c|}{ F1 } & \multicolumn{4}{|c|}{ F2 } & \multicolumn{4}{|c|}{ F3 } & \multicolumn{4}{|c|}{ F4 } & \multicolumn{4}{|c|}{ F5 } \\
\hline & \multicolumn{2}{|c|}{ Jumlah } & \multicolumn{2}{|c|}{ Harga (Rp) } & \multicolumn{2}{|c|}{ Jumlah } & \multicolumn{2}{|c|}{ Harga (Rp) } & \multicolumn{2}{|c|}{ Jumlah } & \multicolumn{2}{|c|}{ Harga (Rp) } & \multicolumn{2}{|c|}{ Jumlah } & \multicolumn{2}{|c|}{ Harga (Rp) } & \multicolumn{2}{|c|}{ Jumlah } & \multicolumn{2}{|c|}{ Harga (Rp) } \\
\hline & g & $\%$ & $\begin{array}{c}\text { Per } \\
\text { g }\end{array}$ & Total & g & $\%$ & $\begin{array}{c}\text { Per } \\
\text { g }\end{array}$ & Total & g & $\%$ & $\begin{array}{c}\text { Per } \\
\text { g }\end{array}$ & Total & g & $\%$ & $\begin{array}{c}\text { Per } \\
\text { g }\end{array}$ & Total & g & $\%$ & $\begin{array}{c}\text { Per } \\
\text { g }\end{array}$ & Total \\
\hline $\begin{array}{l}\text { Tepung } \\
\text { Brown } \\
\text { Rice }\end{array}$ & 80 & 44,9 & 8,5 & 680,0 & 75 & 42,1 & 8,5 & 637,5 & 70 & 39,3 & 8,5 & 595,0 & 65 & 36,5 & 8,5 & 552,5 & 60 & 33,7 & 8,5 & 510,0 \\
\hline Tapioka & 0 & 0,0 & 7,5 & 0,0 & 5 & 2,8 & 7,5 & 37,5 & 10 & 5,6 & 7,5 & 75,0 & 15 & 8,4 & 7,5 & 112,5 & 20 & 11,2 & 7,5 & 150,0 \\
\hline $\begin{array}{l}\text { Tepung } \\
\text { Kedelai }\end{array}$ & 20 & 11,2 & 12 & 240,0 & 20 & 11,2 & 12 & 240,0 & 20 & 11,2 & 12 & 240,0 & 20 & 11,2 & 12 & 240,0 & 20 & 11,2 & 12 & 240,0 \\
\hline Air & 70 & 39,3 & 0,2 & 14,0 & 70 & 39,3 & 0,2 & 14,0 & 70 & 39,3 & 0,2 & 14,0 & 70 & 39,3 & 0,2 & 14,0 & 70 & 39,3 & 0,2 & 14,0 \\
\hline Agar-agar & 5 & 2,8 & 379 & 1893,0 & 5 & 2,8 & 379 & 1893,0 & 5 & 2,8 & 379 & 1893,0 & 5 & 2,8 & 379 & 1893,0 & 5 & 2,8 & 379 & 1893,0 \\
\hline$C M C$ & 1 & 0,6 & 97 & 97,0 & 1 & 0,6 & 97 & 97,0 & 1 & 0,6 & 97 & 97,0 & 1 & 0,6 & 97 & 97,0 & 1 & 0,6 & 97 & 97,0 \\
\hline $\begin{array}{l}\text { Baking } \\
\text { Powder }\end{array}$ & 1 & 0,6 & 87 & 86,7 & 1 & 0,6 & 87 & 86,7 & 1 & 0,6 & 87 & 86,7 & 1 & 0,6 & 87 & 86,7 & 1 & 0,6 & 87 & 86,7 \\
\hline Garam & 1 & 0,6 & 3,6 & 3,6 & 1 & 0,6 & 3,6 & 3,6 & 1 & 0,6 & 3,6 & 3,6 & 1 & 0,6 & 3,6 & 3,6 & 1 & 0,6 & 3,6 & 3,6 \\
\hline $\begin{array}{l}\text { Tartrazine } \\
\text { yellow }\end{array}$ & 0,3 & 0,2 & 113 & 34,0 & 0,3 & 0,2 & 113 & 34,0 & 0,3 & 0,2 & 113 & 34,0 & 0,3 & 0,2 & 113 & 34,0 & 0,3 & 0,2 & 113 & 34,0 \\
\hline Jumlah & 178 & 100 & & 3048,3 & 178 & 100 & & 3043,3 & 178 & 100 & & 3038,3 & 178 & 100 & & 3033,3 & 178 & 100 & & 3028,3 \\
\hline
\end{tabular}

Formulasi yang dihasilkan dari uji tersebut.

program linier merupakan formula optimal dengan kandungan kimia yang memenuhi acuan pembatas yang ditetapkan dengan harga terendah. Dari kelima formula tersebut, F5 merupakan formula dengan harga terendah sebesar Rp. 3.025,2.Namun, untuk menentukan formula terbaik dilakukan uji fisik, organoleptik dan kimia. Sehingga, formula terbaik merupakan

\section{Hasil Uji Fisik Brown Rice Noodle}

Uji fisik yang diteliti meliputi karakteristik adonan, karakteristik mi kering, daya serap air dan cooking loss.

Karakteristik Adonan. Uji coba pembuatan adonan menggunakan Carboxy Methyl Celulose (CMC) tanpa baking powder menghasilkan kukusan adonan sangat 
lengket pada saat pembuatan lembaran mi, sehingga sangat sulit dibentuk lembaran mi. Sedangkan adonan menggunakan baking powder tanpa CMC menghasilkan kukusan adonan lebih berkembang namun sangat rapuh sehingga sangat sulit dibentuk lembaran mi. Oleh karena itu, kombinasi penggunaan $\mathrm{CMC}$ dan baking powder dengan konsentrasi yang sama dapat menghasilkan kukusan adonan yang berkembang namun tidak terlalu rapuh dan tidak lengket saat pembuatan lembaran mi.

Persentase komponen tepung brown rice dan tapioka berdampak pada ekstrusi. Dalam penelitian ini, ekstrusi menggunakan grinder dengan diameter lubang die 0,50 cm. Kukusan adonan yang dihasilkan dari kelima formulasi tersebut, F1 menghasilkan kukusan adonan yang paling sulit dibentuk lembaran karena bentuk kukusan adonan paling rapuh. Sehingga, butuh beberapa kali ekstrusi dalam menghasilkan lembaran mi. Sedangkan F5 menghasilkan kukusan adonan yang paling mudah dibentuk lembaran karena ekstrusi lebih cepat.Jadi, semakin tinggi konsentrasi tapioka dan semakin rendah konsentrasi tepung brown riceakan menghasilkan kukusan adonan yang semakin mudah dibentuk lembaran mi. Menurut Subarna dan Muhandri (2013), proses ekstrusi menyebabkan kompresi terhadap adonan meningkat, sehingga menyebabkan adonan lebih kompak dan lebih mudah dibentuk.

\section{Karakteristik Mi Kering}

Hasil penelitian menunjukkan bahwa mi kering yang paling rapuh dan mudah patah adalah F1. Sedangkan F5 menghasilkan mi yang paling baik dari segi bentuk maupun tekstur. Jadi, semakin rendah konsentrasi tapioka dan semakin tinggi konsentrasi tepung brown riceakan menghasilkan mi kering yang semakin rapuh dan mudah patah.

\section{Daya Serap Air dan Cooking Loss}

Brown rice noodle dapat direhidrasi dalam waktu 3 menit.Waktu rehidrasi tersebut tidak berbeda jauh dengan mi raskin yaitu 4 menit (Hizni \& Sholichin, 2014). Waktu rehidrasi brown rice noodle sama dengan waktu rehidrasi mi terigu selama $3-4$ menit, tapi lebih singkat dari mi 
sagu selama 7 - 9 menit dan mi hotong selama 6,5 menit (Sugiyono, dkk, 2011). Daya serap air dan cooking lossbrown rice noodle dapat dilihat pada Tabel 4.

Tabel 4.Daya serap dan cooking loss dari

\begin{tabular}{ccc}
\multicolumn{3}{c}{ brown rice noodle } \\
\hline Formula & $\begin{array}{c}\text { Daya Serap Air } \\
(\%)\end{array}$ & $\begin{array}{c}\text { Cooking Loss } \\
(\%)\end{array}$ \\
\hline F1 & 66.7 & 52.7 \\
F2 & 95.6 & 38.4 \\
F3 & 107.7 & 30.3 \\
F4 & 103.1 & 27.3 \\
F5 & 138.5 & 17.3 \\
\hline
\end{tabular}

Daya serap air disebabkan proses pemasakan mi yang menyebabkan terjadinya proses gelatinisasi, yaitu proses dimana air terperangkap dalam granulagranula pati yang menyebabkan pembengkakan granula pati dan tidak kembali ke kondisi semula. Pada prosses gelatinisasi terjadi perubahan sifat kimia yang mengakibatkan bahan yang awalnya tidak larut air menjadi larut air. Perubahan sifat fisiko-kimia akan meningkatkan daya serap air (Layalia, 2013).

Tabel 4 menunjukkan bahwa F5 memiliki daya serap air terbesar (138,5\%) dibandingkan formula lainnya. Jika dibandingkan dengan hasil penelitian Sugiyono, dkk (2011), daya serap air brown rice noodle lebih tinggi dibandingkan dengan daya serap mi ubi jalar $(53,23 \%)$ dan mi terigu $(84,77 \%)$.

Cooking loss menunjukkan jumlah padatan yang hilang selama pemasakan. Mi yang bermutu baik adalah mi yang memiliki integritas yang baik selama perebusan, antara lain memiliki jumlah padatan yang hilang yang terdapat pada air rebusannya sangat rendah (Sugiyono, dkk, 2011; Azriani, 2006). Sedangkan menurut Azriani (2006), pada saat tahap pemasakan, sebagian kecil dari mi akan terpisah dari mi dan tersuspensi ke dalam air. Mi kemudian menjadi lembek dan licin, dan air rebusan menjadi keruh dan kental.Peristiwa ini disebut sebagai cooking loss.

Tabel 4.menunjukkan bahwa F5 memiliki cooking loss terkecil (17.3\%) dibandingkan formula lainnya. Jika dibandingkan dengan hasil penelitian Sugiyono, dkk (2011), cooking loss dari brown rice noodle lebih tinggi dibandingkan dengan cooking loss mi ubi jalar (14.85\%) dan mi terigu (11.03\%). 
Daya serap air dan cookingloss sangat erat kaitannya dengan keberadaan gluten. Tidak adanya gluten menyebabkan massa mi kurang kompak dan akibatnya nilai daya serap air rendah tetapi cooking loss tinggi (Sugiyono, dkk, 2011). Akan tetapi, keempat formulasi brown rice noodle (F2, F3, F4 dan F5) memiliki daya serap (95.6 - 138.5\%) yang lebih tinggi dari mi terigu (84.77\%). Hal tersebut dapat disebabkan penggunaan agar-agar yang dapat lebih meningkatkan penyerapan air.Konsekuensi lainnya dari brown rice noodle adalah cooking loss yang tinggi (17.3 - 52.7\%).Tabel 4 menunjukkan bahwa semakin tinggi daya serap air, maka semakin rendah cooking loss-nya.

\section{Hasil Uji Organoleptik Brown Rice Noodle}

Menurut Winarno (2008), penentuan mutu bahan pangan sangat bergantung pada beberapa faktor diantaranya citarasa, warna, tekstur dan nilai gizinya. Salah satu cara mengetahui penerimaan seseorang terhadap produk pangan adalah dengan uji organoleptik, yaitu pengujian yang menggunakan indera manusia sebagai alat utama untuk menilai mutu produk yang meliputi spesifikasi mutu kenampakan, bau, rasa, dan tekstur serta beberapa factor lain yang diperlukan untuk menilai mutu produk tersebut (SNI 01-2346-2006). Dalam penelitian ini, brown rice noodle yang diujikan ke panelis dalam bentuk mi kering sebelum rehidrasi berdasarkan tingkat kesukaan, yaitu kesan subyektif yang sifatnya suka atau tidak suka terhadap warna, aroma, rasa dan tesktur mi (Wagiyono, 2003).

Tabel 5.Rata-rata penilaian organoleptik brown rice noodle

\begin{tabular}{cccccc}
\hline \multirow{2}{*}{ Formula } & \multicolumn{5}{c}{ Nilai Rata-Rata } \\
\cline { 2 - 6 } & Warna & Aroma & Rasa & Tekstur & Rerata \\
\hline F1 & $3,283 \mathrm{a}$ & $3,283 \mathrm{a}$ & $3,450 \mathrm{~b}$ & $2,950 \mathrm{~b}$ & 3,242 \\
F2 & $3,933 \mathrm{~b}$ & $3,717 \mathrm{a}$ & $2,983 \mathrm{a}$ & $2,383 \mathrm{a}$ & 3,254 \\
F3 & $3,967 \mathrm{~b}$ & $3,550 \mathrm{a}$ & $3,583 \mathrm{bc}$ & $3,733 \mathrm{c}$ & 3,708 \\
F4 & $4,350 \mathrm{c}$ & $3,383 \mathrm{a}$ & $3,533 \mathrm{bc}$ & $3,450 \mathrm{c}$ & 3,679 \\
F5 & $4,533 \mathrm{c}$ & $3,667 \mathrm{a}$ & $3,800 \mathrm{c}$ & $3,900 \mathrm{c}$ & 3,975
\end{tabular}

Keterangan: setiap huruf yang berbeda menyatakan berbeda nyata pada taraf $5 \%$

\section{Warna}

Menurut Wagiyono (2003), warna adalah kesan yang dihasilkan oleh indra mata indra terhadap cahaya yang dipantulkan oleh benda. Sedangkan 
menurut Meilgaard, Civille dan Carr (1999), warna adalah suatu fenomena meliputi komponen fisik dan psikologi.

Secara visual, kadang-kadang warna muncul terlebih dahulu dan sangat menentukan mutu pangan. Warna dapat juga digunakan sebagai indikator kesegaran atau kematangan dengan mengetahui baik atau tidaknya cara pencampuran atau cara pengolahan yang dapat diketahui dengan adanya keseragaman warna (Winarno, 2008).

Tabel 5 menunjukkan bahwa $\mathrm{F} 1$ berbeda nyata dengan formula lainnya, F2 tidak berbeda nyata dengan F3, begitupun F4 tidak berbeda nyata dengan F5. Namun, F2 dan F3 berbeda dengan F4 dan F5.Perbedaan warna dapat disebabkan faktor perbedaan konsentrasi campuran tepung brown rice dan tapioka, dimana tepung brown rice berwarna putih kusam, sedangkan tapioka berwarna putih bersih. Dalam penentuan formula terbaik berdasarkan parameter warna, peneliti menetapkan F5 dengan nilai rata-rata tertinggi yaitu 4,533, meskipun secara statistik tidak berbeda nyata dengan F4.

\section{Aroma}

Aroma adalah rangsangan yang berasal dari substansi zat yang menguap atau terlarut dalam udara dari produk pangan dan kontak atau bersentuhan dengan sel peka pada rongga hidung "olfaktori" sehingga menimbulkan kesan tertentu (Wagiyono, 2003; Meilgaard, Civille \& Carr, 1999; Winarno, 2008). Menurut Winarno (2008), aroma menentukan kelezatan pangan.

Tabel 5 menunjukkan bahwa semua formula tidak berbeda nyata. Hal tersebut dikarenakan menggunakan bahan baku yang sama, hanya dibedakan pada konsentrasi campuran tepung brown rice dan tapioka. Kedua tepung tersebut tidak memiliki aroma yang tajam, sehingga menghasilkan aroma yang tidak berbeda nyata.Karena secara statistik tidak ada perbedaan antar formula, maka penentuan formula terbaik dapat ditentukan secara bebas. Dalam penelitian ini, peneliti 
menetapkan F2 merupakan aroma terbaik dengan nilai rata-rata 3,717 .

\section{Rasa}

Penginderaan cecapan meliputi empat cecapan utama yaitu asin, asam, manis dan pahit. Rasa dipengaruhi oleh beberapa factor yaitu senyawa kimia, suhu, konsentrasi dan interaksi dengan komponen rasa yang lain (Winarno, 2008).

Rasa adalah adalah karakteristik dari suatu zat yang disebabkan oleh adanya bagian zat tersebut yang larut dalam air atau minyak atau lemak dan bersentuhan atau kontak dengan indra pencicipan (lidah dan rongga mulut), sehingga memberikan kesan tertentu. (Wagiyono, 2003; Meilgaard, Civille \& Carr, 1999).

Tabel 5 menunjukkan bahwa F1, F3, F4 dan F5 tidak berbeda nyata, namun berbeda nyata dengan F2.Perbedaan rasa dapat disebabkan karena perbedaan konsentrasi campuran tepung brown rice dan tapioka. Penentuan formula terbaik berdasarkan parameter rasa, peneliti menetapkan F5 dengan nilai rata-rata tertinggi yaitu 3,800 , meskipun secara statistik tidak ada perbedaan dengan F1, F3 dan F4.

\section{Tekstur}

Tekstur adalah atribut penilaian produk pangan untuk mengetahui yang padat atau semipadat (Meilgaard, Civille \& Carr, 1999). Tekstur suatu bahan pangan akan mempengaruhi cita rasa yang ditimbulkan oleh bahan pangan tersebut karena mempengaruhi kecepatan timbulnya rangsangan terhadap sel reseptor olfaktori dan kelenjar air liur (Winarno, 2008).

Tabel 5 menunjukkan bahwa $\mathrm{F} 1$ berbeda nyata dengan formula lainnya, begitupun dengan F2. Sedangkan F3, F4 dan F5 tidak berbeda nyata. Perbedaan dapat disebabkan perbedaan pemerataan panas yang diterima produk saat pengeringan akibat perbedaan volume produk dalam alat pengering, sehingga terjadi tingkat kekeringan brown rice noodle yang berbeda. Penentuan formula terbaik berdasarkan parameter tekstur, peneliti menetapkan F5 dengan nilai rata-rata tertinggi yaitu 3,900, meskipun tidak ada perbedaan dengan F3 dan F4. 


\section{Rerata}

Menurut Hizni dan Sholichin (2014), formulasi produk terbaik dapat ditentukan berdasarkan rata-rata penilaian keseluruhan atau kumulatif terhadap hasil uji organoleptik terhadap atribut warna, aroma, rasa dan tekstur.Tabel 4 menunjukkan bahwa secara keseluruhan, formulasi terbaik adalah F5 dengan nilai rata-rata tertinggi yaitu 3,975. Pertimbangan penentuan formula terbaik berdasarkan hasil uji organoleptik adalah hasil tersebut menunjukkan selera konsumen yang diwakili oleh panelis.

\section{Hasil Uji Kimia Brown rice Noodle}

Pengujian kimia berguna untuk mengetahui apakah kadar kimia masingmasing formula telah memenuhi persyaratan SNI mi kering atau tidak. Respon kimia dalam penelitian ini adalah kandungan kimia yang dijadikan faktor pembatas dalam formulasi bahan baku, yaitu kadar protein dan kadar air. Tabel 6 menunjukkan hasil analisis kimia Brown Rice Noodle dari kelima formulasi.

Tabel 6. Hasil analisis kimia brown rice noodle

\begin{tabular}{ccc}
\hline Formula & $\begin{array}{c}\text { Kadar } \\
\text { Protein }(\%)\end{array}$ & Kadar Air (\%) \\
\hline F1 & 13,50 & 6,90 \\
F2 & 12,94 & 8,26 \\
F3 & 13,14 & 6,41 \\
F4 & 12,30 & 6,66 \\
F5 & 11,61 & 7,19 \\
\hline
\end{tabular}

Kadar protein brown rice noodle dari kelima formulasi telah memenuhi syarat SNI 01-2974-1996 tentang syarat mutu I mi kering, yaitu kadar protein minimal $11 \%$. Syarat minimal kadar protein brown rice noodle terpenuhi dari penggunaan tepung kacang kedelai sebagai sumber protein.

Perbedaan kadar protein brown rice noodle dapat disebabkan karena perbedaan konsentrasi campuran tepung brown rice dan tapioka, dimana kedua komponen tersebut memiliki kadar protein yang berbeda. Kadar protein tepung brown rice sebesar 2,48\%, sedangkan kadar protein tapioka sebesar $0,50 \%$. Faktor perbedaan lainnya karena perbedaan panas yang diterima bahan saat proses pembuatan produk.

Perbedaan kadar protein dapat disebabkan kolapsnya struktur protein akibat timbulnya panas selama proses pengulian/pengadukan adonan. Proses tersebut menyebabkan energy kinetik 
molekul-molekul bahan dalam adonan menjadi besar, sehingga menyebabkan perubahan energy dari bahan adonan. Hal ini akan mempengaruhi kapasitas panas bahan serta menyebabkan penurunan kadar protein. Pada saat pembentukan lembaran mi juga menyebabkan timbulnya panas karena friksi antara bahan dengan permukaan roll alat, yang dapat menurunkan kadar protein (Layalia, 2013).

Pengukusan adonan dan pengeringan menyebabkan terjadinya denaturasi protein akibat panas yang ditimbulkan, sehingga terjadi penurunan kadar protein (Layalia, 2013). Pada penelitian ini, perbedaan kadar protein dapat disebabkan tidak meratanya panas yang diterima produk saat proses pengeringan karena perbedaan volume produk dalam alat pengering.

Kadar air merupakan persentase kandungan air suatu bahan (Syarif \& Halid, 1992). Kelima formulasi menunjukkan kadar air yang berbeda. Namun, keempat formulasi telah memenuhi syarat SNI 012974-1996 tentang syarat mutu I mi kering, yaitu kadar air maksimal 8\%. Kecuali F2 memiliki kadar air sedikit lebih tinggi 0,26\% dari syarat mutu SNI.

Perbedaan kadar air brown rice noodle dapat disebabkan karena perbedaan konsentrasi campuran tepung brown rice dan tapioka, dimana kedua komponen tersebut memiliki kadar air yang berbeda. Kadar air tepung brown rice sebesar $15,58 \%$, sedangkan kadar air tapioka sebesar $12,00 \%$. Faktor perbedaan lainnya terjadi karena proses pengolahan yaitu perbedaan ketebalan adonan yang dipipihkan, sehingga mempengaruhi penyerapan uap air oleh adonan pada saat pengukusan. Faktor lainnya adalah tidak meratanya panas yang diterima produk saat proses pengeringan karena perbedaan volume produk dalam alat pengering.

Parameter kadar air perlu diperhatikan karena memiliki peranan penting yaitu sebagai salah satu faktor yang mempengaruhi aktivitas mikroba. Semakin tinggi kadar air, maka semakin tinggi aktivitas mikroba yang pada akhirnya akan mempercepat kerusakan bahan pangan. 
selain itu, kadar air juga mempengaruhi sifat fisik seperti tekstur dan citarasa (Syarif \& Halid, 1992).

\section{KESIMPULAN}

Aplikasi program linier bermanfaat dalam mengoptimalkan formulasi produk dengan biaya rendah namun dapat memenuhi kandungan kimia yang dikehendaki sesuai standar produk yang ada. Berdasarkan uji fisik, F5 merupakan produk terbaik karena memiliki karakteristik adonan yang paling mudah dibentuk menjadi mi, mi kering dengan bentuk dan tekstur terbaik, serta memiliki daya serap air tertinggi $(138.5 \%)$ dan cooking loss terendah (17.3\%). Secara organoleptik, F5 merupakan produk terbaik dengan nilai ratarata terhadap atribut warna, aroma, rasa dan tekstur sebesar 3,975 . Semua produk telah memenuhi persyaratan mutu I mi kering yaitu kadar air maksimal $8 \%$ dan kadar protein minimal $11 \%$, kecuali kadar air F2 sedikit lebih tinggi dari ketetapan.

\section{DAFTAR PUSTAKA}

Arfani, F 2012, Indonesia Tertinggi Kedua Asia Konsumsi Mi Instan, 11 April 2014,http://jatim.antaranews.com/lihat /berita/81851/indonesia-tertinggikedua-asia-konsumsi-mi-instan.

Azriani Y 2006, 'Pengaruh Jenis Kemasan Plastik Dan Kondisi Pengemasan Terhadap Kualitas Mi Sagu Selama Penyimpanan', Skripsi, Fakultas Teknologi Pertanian, Institut Pertanian Bogor.

Beranda 2013, 10 Bahan Pangan Indonesia Masih Impor, 25 Maret 2014, http://beranda.miti.or.id/10-bahanpangan-indonesia-masih-impor/.

Charutigon, C, Jitpuprakdee, J, Namsree \& Rungsardthong, V 2008, 'Effects of Processing Conditions and The Use of Modified Starch and Monoglyceride on Some Properties of Extruded Rice Vermicelli', LWT Food Science Technology 41: 642-651. DOI:10.1016/j.Iwt.2007.04.009.

Cuevas, R P, Daygon, V D, Corpuz, H, Nora, L, Reinke, R, Waters, D \& Fitzgerald, M 2010. 'Melting the secrets of gelatinization temperature in rice', Presented at the 28th International Rice Research Conference, 8-12 November 2010, Hanoi, Vietnam OP10: Quality Grain, Health, and Nutrition.

Hasnelly 2011, 'Winning Strategies Value Creation of Customer Loyalty of Green Food Product', Journal of Asia Pacific Business Innovation \& Technology Management 001 (2011) 0047-0059.

Herjanto, E. 2008, Manajemen Operasi (Edisi Ketiga), Jakarta, Grasindo.

Hizni, A \& Sholichin 2014, 'Pemanfaatan Mi Raskin (Beras Untuk Rakyat Miskin) Sebagai Makanan Tambahan Bagi Anak Bawah Lima Tahun (Balita) Kekurangan Gizi', Buletin Media Informasi Poltekkes Kemenkes Tasikmalaya, Edisi 2 Tahun 2014. 
Khomsan, A, Baliwati, Y F \& Dwiriani, C M 2010, Pengantar Pangan dan Gizi, Jakarta, Penebar Swadaya.

Kabar24 2012, Mi Instan, Orang Indonesia Konsumen Kedua Terbanyak, 11 April 2014, http://www.kabar24.com/index.php/miinstan-orang-indonesia-konsumenkedua-terbanyak/.

Layalia, L H 2013, 'Optimalisasi Formulasi Pembuatan Mi Basah Campuran Pasta Ubi Ungu (Ipomea batatas L.) dengan Program Linier', Skripsi, Jurusan Teknologi Pangan, Fakultas Teknik, Universitas Pasundan.

Marti A, Seetharaman K, \& Pagani M A 2010, 'Rice-Based Pasta: A Comparison Between Conventional Pasta-Making and Extrusion-Cooking', Journal Cereal Science 52: 404-409. DOI: 10.1016/j.jcs.2010.07.002.

Meilgaard, M, Civille, G V \& Carr, B T 1999. Sensory Evaluation Techniques, $3^{\text {rd }}$ edition. USA, CRC Press.

Merdeka, 2013, Impor Besar Karena Orang Indonesia Hobi Makan Mi Instan Dan Roti, $25 \quad$ Maret 2014, http://m.merdeka.com/uang/imporbesar-karena-orang-indonesia-hobimakan-mi-instan-dan-roti.html.

Merdiyanti, A 2008, 'Paket Teknologi Pembuatan Mi Kering Dengan Memanfaatkan Bahan Baku Tepung Jagung', Skripsi, Departemen IImu Dan Teknologi Pangan, Fakultas Teknologi Pertanian, Institut Pertanian Bogor.

Persagi (Persatuan Ahli Gizi) 2009, Tabel Kompoisi Pangan Indonesia, Jakarta, Persagi.

Sindonews 2013, DPR cemaskan ketergantungan impor gandum, 25
Maret 2014 ,

http://ekbis.sindonews.com/read/2013 /05/07/34/746066/dpr-cemaskan ketergantungan-impor-gandum.

Siringoringo, H 2005, Seri Teknik Riset Operasional: Pemrograman Linear, Yogyakarta, Graha IImu.

SNI 01-2346-2006. Petunjuk Pengujian Organoleptik dan atau Sensori, Jakarta, Badan Standarisasi Nasional.

SNI 01-2974-1996. Syarat Mutu Mi Kering, Jakarta, Badan Standarisasi Nasional.

Subarna \& Muhandri, T 2013, 'Pembuatan Mi Jagung Kering dengan Metode Kalendering', Jurnal Teknologi dan Industri Pangan 24: 75-80.

Sugiyono, Setiawan, E, Syamsir, E \& Sumekar, H 2011, 'Pengembangan Produk Mi Kering dari Tepung Ubi Jalar (Ipomoea batatas) dan Penentuan Umur Simpannya dengan Metode Isoterm Sorpsi', Jurnal Teknologi dan Industri Pangan, Vol. XXII No. 2 Th. 2011, hal. $164-170$.

Syarif, R \& Halid, H 1992. Teknologi Penyimpanan Pangan, Jakarta, Arcan.

Tabloid Pasar 2012, Penjualan Milnstan Indonesia Terbesar Kedua, 11 April 2014, http://tabloidpasar.com/penjualan-miinstan-indonesia-terbesar-kedua/.

Tempo 2013, Indonesia Didesak Kurangi Impor Gandum, 25 Maret 2014, http://www.tempo.co/read/news/2013/ 07/24/090499391/Indonesia-DidesakKurangi-Impor-Gandum.

Wagiyono 2003, Menguji Kesukaan Secara Organoleptik, Jakarta, Bagian Proyek Pengembangan Kurikulum, Direktorat Pendidikan Menengah Kejuruan, Direktorat Jenderal Pendidikan Dasar 
Dan Menengah,

Departemen

Winarno, F G 2008, Kimia Pangan dan Gizi,

Pendidikan Nasional. Bogor, Mbrio Press. 